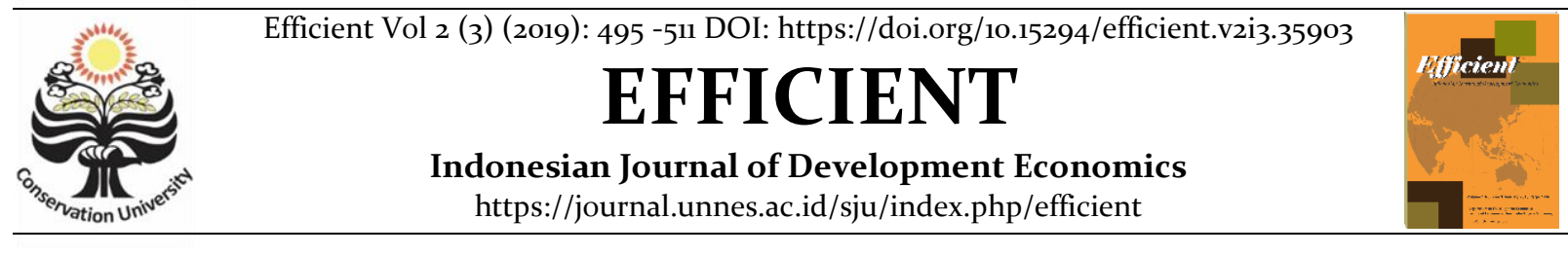

\title{
The Existence of Post Reform Agricultural Extension Institutional
}

\author{
Devie Purwitasari ${ }^{凶}$ \\ Jurusan Ekonomi Pembangunan, Fakultas Ekonomi, Universitas Negeri Semarang \\ Permalink/DOI: https://doi.org/10.15294/efficient.v2i3.35903
}

Received: Juny 2019 ; Accepted: September 2019; Published: December 2019

\begin{abstract}
The purpose of this study is to analyze the existence of agricultural extension institutions in Central Java Province. The variables used include institutional changes and the impact of institutional changes. The method of data analysis in this study is a descriptive qualitative method with the model of Miles and Huberman with the validity test of triangulation data. The types of data used are primary data from the Agriculture and Plantation Office of Central Java Province, the Office of Environment and Forestry of Central Java Province, the Semarang City Fisheries Office and Farmers in Central Java Province. Retrieval of data through in-depth interviews, document collection, and documentation. The results showed that institutional change was very dynamic since the formation of the institution. Institutional changes occur because of the evolution of laws and their forced nature. Therefore the institution of agricultural extension does not exist. However, so far the community is still getting a good impact from the extension activities because institutional changes do not reduce the performance of extension workers in the community. It's just that extension workers have not been intensive because the numbers are very minimal. This is overcome by the instructor by making a priority when conducting counseling.
\end{abstract}

Keywords: Agricultural Extension, Institutional, Institutional Change, Institutional Existence, Impact Of Extension

\begin{abstract}
Abstrak
Tujuan penelitian ini adalah untuk menganalisis eksistensi kelembagaan penyuluhan pertanian di Provinsi Jawa Tengah. Variabel yang digunakan meliputi perubahan kelembagaan dan dampak perubahan kelembagaan. Metode analisis data dalam penelitian ini adalah metode deskriptif kualitatif dengan model Miles dan Huberman dengan uji keabsahan data triangulasi. Jenis data yang digunakan adalah data primer dari Dinas Pertanian dan Perkebunan Provinsi Jawa Tengah, Dinas Lingkungan Hidup dan Kehutanan Provinsi Jawa Tengah, Dinas Perikanan Kota Semarang dan Petani di Provinsi Jawa Tengah. Pengambilan data melalui wawancara mendalam, pengumpulan dokumen, dan dokumentasi. Hasil penelitian menunjukkan bahwa perubahan kelembagaan sangat dinamis sejak dibentuknya kelembagaan. Perubahan kelembagaan terjadi karena evolusi undang-undang dan sifatnya dipaksakan. Oleh karena itu kelembagaan penyuluhan pertanian sudah tidak eksis. Namun, sejauh ini masyarakat masih tetap mendapatkan dampak baik dari kegiatan penyuluhan karena perubahan kelembagaan tidak mengurangi kinerja penyuluh di masyarakat. Hanya saja penyuluh belum intensif karena jumlahnya sangat minim. Hal ini diatasi oleh penyuluh dengan membuat prioritas saat melakukan penyuluhan.
\end{abstract}

Kata Kunci: Penyuluhan Pertanian, Kelembagaan, Perubahan Kelembagaan, Eksistensi Kelembagaan, Dampak Penyuluhan

How to Cite: Purwitasari, D. (2019). The Existence of Post Reform Agricultural Extension Institutional. Efficient: Indonesian Journal of Development Economics, 2(3), 495-511. https://doi.org/10.15294/efficient.v2i3.35903

(c) 2019 Semarang State University. All rights reserved

\footnotetext{
Alamat Korespondensi :

Alamat: Gedung L2 Lantai 2 FE Unnes

Kampus Sekaran, Gunungpati, Semarang, 50229

E-mail : deviepurwitasari94@yahoo.com
} 


\section{INTRODUCTION}

Education for farmers to pr6vide knowledge about agriculture is an effort to improve the quality of agriculture in Indonesia. According to Rahim M. Sail in Prajanti (2011), agricultural extension is an informal education that tries to bring changes in knowledge, attitudes, and activities of clients following the elements of education through a participatory approach. Farmers try to solve their problems before deciding to accept or reject new technology. Agricultural extension workers as leaders who empower farmers to focus on developing the potential of farmers by taking care of, lead, solve problems, and make decisions in the interests of farmers (Prajanti, 2011).

Efforts to improve the quality of agriculture will be better if it improves the ability of farmers to carry out better farming. There are several ways to empower agriculture including education and training, counseling and assistance, developing systems and means of marketing agricultural products, consolidation, and guarantee of agricultural land area, easy access to science, technology and information, and strengthening farmer institutions (Saputri R.D., 2016).

The formation of agricultural extension institutions because it is an agricultural development effort that is seen as a transformation process will bring changes in the allocation of economic resources, the process of distribution of benefits and accumulation processes that bring increased production, income, and welfare.

According to Puspitasari in Prajanti (2011), the performance of agricultural instructors is defined as the ability of extension agents to actualize the implementation of their duties. Agricultural extension is needed by farmers for education to improve the quality of agriculture and agricultural productivity. Since the enactment of Law Number 22 of 1999 concerning regional autonomy, the condition of agricultural counseling began to suffer. This was preceded by the implementation of the concept of regional autonomy, in which the authority in the field of agricultural extension since 2001 was delegated to local governments so that the region can improve the performance of agricultural extension workers. In reality, local government policies in the last few years have not been pro-active towards agricultural extension-related activities so that the performance of agricultural extension has declined.

Efforts are continuously made by the government in the form of agricultural revitalization to drive the sector in agriculture in developing the economy. In accordance with the mandate of Law Number 16 of 2006, the government extension institution at the central level is in the form of a body that handles extension services (Bakornas) and then at the provincial level a Counseling Coordination Agency is formed, at the City District level an Agricultural, Fisheries and Forestry Counseling Agency (Bapelluh) is formed, and at the sub-district level, it takes the form of an Extension Center.

The distribution of extension institutions in Indonesia is so centrally coordinated that each region has an agricultural instructor who will carry out its task of providing education to the public in 2013. However, its effectiveness has declined since the issuance of Law Number 14 of 2014 concerning Regional Government where instructors who number around 36,0oo people are not can be mobilized properly to 
the district/ city, so their productivity is very low (Nuhung, 2016).

Central Java Provincial Government is one of the regions holding autonomy mandates that are obliged to manage economic resources that are shared with the community, form partnerships with the private sector to create jobs and encourage regional economic growth to become the authority of the provincial government so that poverty levels are reduced through reducing income gap between residents, between regions and between sectors in Central Java Province. If you pay attention to the distribution of extension institutions in Indonesia, Central Java Province is included as an institution in the form of Extension Coordination Agency established by governor regulation which is a follow-up mandate of Law Number 16 Year 2006 concerning Agricultural, Fisheries and Forestry Extension Systems.

Based on the results of internal and external analysis of agricultural and plantation development problems faced in the form of conditions that pose opportunities and threats within 5 years. One of the problems that need to get attention in the development of agriculture and plantations during the 5 years from 2013 to 2018 is the limited number of civil servant extension workers, pest observers, and plant seed supervisors because many are entering retirement. Another problem in conducting counseling is the lack of capacity building facilities for self-help extension workers. Even the problem of the low quality of extension services institutions and the main actors of business actors, the low competency of extension human resources and the main actors of business actors according to their fields of expertise, ineffective implementation of effective, efficient, and accountable counseling is a strategic issue in agricultural and plantation development.

In Central Java Province, increasing human resources and agricultural extension into development programs that support the government's mission to realize the welfare of the community that is just, alleviates poverty, and unemployment in the goal of ensuring food sovereignty through availability (food production and reserves), affordability, food consumption and nutrition and security and security food based on raw materials, resources and local wisdom.

The issuance of Law Number 23 of 2014 along with the preparation of the 2013-2018 Agriculture and Plantation Service Strategic Plan. So, the impact of the Act can also be known according to the year of implementation based on the performance indicators of the agriculture and plantation service in Central Java Province which refers to the objectives and targets of the RPJMD shown in the target indicators for the number of quality extension centers and the growth of Posluhdes and the percentage of extension workers who have competency in the area of expertise which will be explained in Table 1.

Based on Table 1., the number of quality extension centers and the growth of Posluhdes compared to the 2008-2012 period where the number of extension centers always increased, the number did not increase starting from 2015 some 378 units but started to increase by 20 units each year from 2016 until 2018. Likewise, the number of Posluhdes that increased from 2013 to 2018 was 100 units in 2014 and 50 units annually from 2015 to 2018. 
An increase in the percentage of extension workers who have competencies with expertise as much as 5.99 percent from 2013 to 2014, then an increase in the percentage of extension workers who have competencies with expertise as much as 10 percent per year from 2015 to 2018. Increasing the number of extension centers accompanied by an increase in the availability of human resources extension agents due to extension has an important role to support the increase in production and productivity of agricultural products, plantations, and livestock.

Table 1. Performance Indicators of the Agriculture and Plantation Office of Central Java Province Referring to the RPJMD's Objectives

\begin{tabular}{|c|c|c|c|c|c|c|c|}
\hline Target Indicator & $\begin{array}{l}\text { Performance } \\
\text { conditions at } \\
\text { the beginning } \\
\text { of the RPJMD } \\
\text { period }\end{array}$ & Perfo & mance & Target & & & $\begin{array}{l}\text { Performance } \\
\text { conditions at the } \\
\text { end of the } \\
\text { RPJMD period }\end{array}$ \\
\hline Year & 2013 & 2014 & 2015 & 2016 & 2017 & 2018 & 2018 \\
\hline $\begin{array}{l}\text { Number of quality } \\
\text { counseling centers } \\
\text { and the growth of } \\
\text { Posluhdes (unit) }\end{array}$ & 527 and 3233 & & $\begin{array}{l}378 \\
\text { and } \\
3333\end{array}$ & $\begin{array}{l}398 \\
\text { and } \\
3383\end{array}$ & $\begin{array}{l}418 \\
\text { and } \\
3433\end{array}$ & $\begin{array}{l}438 \\
\text { and } \\
3483\end{array}$ & 438 and 3483 \\
\hline $\begin{array}{l}\text { Percentage } \\
\text { Extension } \\
\text { Who Workers } \\
\text { Competency in the } \\
\text { Field of Expertise (\%) }\end{array}$ & 34.01 & 40 & 50 & 60 & 70 & 80 & 80 \\
\hline
\end{tabular}

Source: 2013-2014 Agriculture and Plantation Service Strategic Plan

In Central Java Province, increasing the Ministry of Environment and Forestry human resources and agricultural extension is the development programs that support the government's mission to realize the welfare of the community that is just, alleviates poverty, and unemployment in the goal of ensuring food sovereignty through availability (food production and reserves), affordability, food consumption and nutrition and security and security food based on raw materials, resources and local wisdom.

The performance of forestry extension activities is assessed from the four target indicators based on the Work Plan of the Extension Center for Human Resources and Human Resources Development and Development which consists of increasing the class of forest farmer groups from beginner to intermediate classes, the formation of farmer group cooperative groups, the establishment of Forestry Apprenticeship Training Institutions Self-help (LP2UKS), and increased capacity for reliable assistants for the Forest Farmer Group $(\mathrm{KTH})$ in community empowerment in forest villages. The following is the condition of the performance of extension activities in Central Java Province which will be explained in Table 2. 
Table 2. Performance Achievements in Forestry Extension Activities in Central Java Province

Indicators of Work Activities Year

\begin{tabular}{llll} 
& & 2017 & 2018 \\
\hline Increasing the class of farmer & 30 & 15
\end{tabular}

groups from beginner to intermediate $(\mathrm{KTH})$

Increase in the number of $1 \quad 2$ cooperatives (units)

Improvement of the Self- 1 o Supporting Forestry Business

Apprenticeship Training Institute

(LP2UKS) (unit)

Increased reliable assistants for 40 o

KTH in community

empowerment in forest villages

(people)

Source: 2018 Counseling Center Work Plan Achievement Report

Based on Table 2., the performance improvement of extension services in Central Java Province in the form of an increase in the class of farmer groups of forest villages from the beginner to intermediate level of $30 \mathrm{KTH}$ in 21 districts in 2017, then $15 \mathrm{KTH}$ in 5 districts in 2018. In terms of increasing the number of KTH cooperatives, in 2017 cooperatives formed some 1 unit, then 2 cooperatives in 2018. Increasing the number of Non-Governmental Forestry Business Apprenticeship Training Institutions ( $\mathrm{LP}_{2} \mathrm{UKS}$ ) by 1 unit in 2017. In increasing the number of reliable assistants for $\mathrm{KTH}$ in community empowerment in forest villages as many as 40 people, then there was no increase in 2018.

Workers' work performance is assessed based on the Main Indicators of the Maritime Research and Fisheries and Human Resources Agency (BRPSDMKP). Based on the results of the post-training evaluation, the following Table 5 details the contribution of performance achievements from each Work Unit :

Table 3. Details of Contribution of Performance Achievement from Each Working Unit in 2017

\begin{tabular}{llll}
\hline Work Unit & Training Graduates (People) & Increases Production & Level of achievement \\
\hline BPPP Medan & 1080 & 598 & 55.37 \\
BPPP Tegal & 1790 & 1160 & 64.80 \\
BPPP & 1590 & 1070 & 67.30 \\
Banyuwangi & & & \\
BPPP Bitung & 990 & 430 & 43.43 \\
BPPP Ambon & 840 & 504 & 60.00 \\
Jumlah & 6290 & 3762 & 59.81 \\
\hline
\end{tabular}

Source: Maritime and Fisheries Research and Human Resources Agency (BRPSDMKP), 2017

Based on Table 3., it can be seen that BPPP Tegal which oversees fisheries instructors in Central Java Province has the highest training graduates as many as 1790 people and the highest increase in production by 1160 tons but the second-highest level percent after BPPP Banyuwangi, amounting to 64.80 percent. Central Java Province contributed 72 groups with 720 members which is the highest contribution of national training graduates. Another achievement of the performance of agricultural extension 
activities in the form of increased distribution of groups which increased in class by 105 groups that increased from beginner class groups to middle class groups.

Based on the achievement of the performance of activities and improving the quality of agricultural extension is expected to increase agricultural output which is known based on the GRDP of the agricultural sector. Central Java Province is the second highest contributor to gross regional domestic product in the agriculture sector after East Java nationally from 2013 to 2018 with relatively increased production starting in 2015 from until 2017. This makes Central Java Province also one of the supporting provinces national food (Province of Central Java in Figures, 2018).

The increase in the GDP of the agricultural sector was not proportional to its growth when compared to other provinces. Central Java Province ranks second lowest in growth. The following is the GRDP growth of the agricultural sector in the five provinces with the highest GRDP nationally in Table 4.

Table 4. Growth of Gross Regional Domestic Product in Agriculture Sector in 2014-2017

\begin{tabular}{llllll}
\hline Province & 2014 & 2015 & 2016 & 2017 & Average \\
\hline Sumatera Utara & 4.37 & 5.57 & 4.65 & 5.31 & 4.97 \\
Riau & 6.15 & 0.43 & 3.98 & 5.28 & 3.96 \\
Jawa Timur & 3.54 & 3.28 & 2.41 & 1.48 & 2.67 \\
Jawa Tengah & -0.95 & 5.60 & 2.28 & 1.46 & 2.10 \\
Jawa Barat & 0.29 & 0.16 & 5.64 & 1.88 & 1.99 \\
\hline
\end{tabular}

Source: Animal Husbandry and Animal Health Statistics, 2019, processed

Based on Table 4., it can be seen that the GRDP growth of the agricultural sector at the level of Central Java Province is not comparable to the increase in the number of GRDP in the agricultural sector. This is indicated by the relatively low growth rate of Central Java Province compared to other provinces. In 2014 the GRDP growth in the agricultural sector was negative by -0.95 due to a decline in production from 2013 to 2014 from 108,321.1 to 107,793.4. This decrease coincided with the issuance of the regional autonomy law, the decline continued in 2016 from 5.60 to 2.28 and decreased again in 2017 to 1.46 after the regional autonomy law was adopted. Efforts to improve the quality and number of institutions have indeed been carried out and the results are good based on Tables 2, 3, 4, but have not been able to increase the GRDP growth in the agricultural sector.

Historical review of extension activities in Indonesia shows that there are interesting dynamics related to extension from the postreformation period to the present. Institutional extension is indeed always changing in every era. Starting from the era before independence, after that agricultural extension workers proceed from the era of the old order (post-independence), the era of the new order, the era of reform, and post-reform experienced changes in the area of work, institutions, and the number of extension workers.

Some regions do experience differences in extension services according to the mandate of the regional autonomy law. By paying attention to previous historical descriptions, 
the performance achievements of agricultural extension activities, gross regional domestic product, and observing the regional autonomy law, the law on agricultural extension systems, fisheries, and forestry, and the Regional Government Law and the problems faced in the implementation of extension activities. It is necessary to know how the development of agricultural instructors from time to time in Central Java as a study and evaluation of the implementation of extension services, the existence of agricultural extension institutions as agricultural extension ties, and the impact of changes in agricultural extension institutions for the community.

Based on the background that has been explained, the researcher follows the theme of agricultural extension by taking the title of Institutional Analysis of Agricultural Reform Post-Reformation in Central Java Province With the formulation of the problem as follows: 1). How institutional changes in agricultural extension in post-reform Central Java Province? 2) What is the impact of changing agricultural extension institutions for farming communities in Central Java Province? 3) What is the impact of reforms on agricultural extension institutions in Central Java Province?

The objectives of the study are as follows:

1). To analyze institutional changes in agricultural extension in the post-reform era in Central Java. 2) To analyze the impact of institutional changes in agricultural extension for the farming community in Central Java Province. 3) To analyze the impact of reforms on agricultural extension institutions in Central Java Province.

\section{METHOD}

This study is a qualitative research with descriptive analysis method. The qualitative descriptive format is generally carried out in this study in the form of case studies with the units studied are individuals, groups / families, communities, and social institutions / institutions, where this study can be very indepth and so that the depth of the data under consideration in research (Bungin, 2017).

The purpose of this study was to analyze changes in institutional agricultural extension in the post-reform era of Central Java Province, analyze the impact of changes in agricultural extension institutions for farming communities in Central Java Province, and analyze the impact of reforms on agricultural extension institutions in Central Java Province. The research technique used survey techniques. Sampling by purposive sampling is Keyperson. The focus of this research consists of institutional change, institutional existence, and the impact of institutional change. The locus of research is in the Province of Central Java with specifications to the Office of Environment and Forestry of the Province of Central Java, the Office of Agriculture and Plantation of the Province of Central Java, and the Office of Fisheries of the City of Semarang.

The variable used consists of institutional changes in agricultural extension with indicators of the phase/model of institutional change in the historical context, causes of institutional changes, types of institutional changes. Variable impact of institutional changes for the community with indicators of government involvement, benefits gained, losses obtained. Variable impact of reforms on institutional change with indicators of the stage of institutional formation, legal organizational structure, institutional change, 
program impacts and institutional impacts for the community.

Data validity testing conducted by researchers refers to Denzin (1978) in Bungin, 2011: 264) where the technical implementation of the validity testing step refers to researchers, sources, methods, and theories. Analysis of the model data used by Miles and Huberman. Activities in data analysis consist of data reduction, data presentation, conclusion drawing, and verification.

\section{RESULTS AND DISCUSSION}

\section{Institution of Agricultural Extension in Central Java Province}

Agricultural extension institutions are groups or organizations that carry out agricultural extension activities. In Central Java Province, counseling activities are carried out by some instructors, namely civil servants (Civil Servants), self-help instructors, and private extension workers. Civil Servant Extension Workers are merged into one in Bakorluh (Extension Coordination Agency) according to the mandate of Law Number 16 of 2006 concerning the Counseling System. When Law Number 16 of 2006 concerning Counseling Systems has not been revoked, then Law Number 23 of 2014 concerning the Regional Government regulates extension institutions so that they join the relevant agencies.

Agricultural and plantation counseling currently has institutions up to the district level under the auspices of the Agriculture and Plantation Office, forestry extension has institutions up to the provincial level under the auspices of the Department of Environment and Forestry, and education on fisheries is returned to the center at the
Ministry of Maritime Affairs and Fisheries. divided into nine Satminkal (Pangkal Administrative Unit) in Indonesia with an average of 3-4 provinces per Satminkal with $\mathrm{BP}_{3}$ institutional (Fisheries Counseling Training Center).

According to the Law of the Republic of Indonesia Number 16 Year 2006 Concerning Agriculture, Fisheries and Forestry Extension Systems $\left(\mathrm{SP}_{3} \mathrm{~K}\right)$ extension in agriculture is divided into agricultural, fisheries and forestry extension services. Agricultural counseling includes food crops, horticulture, plantations, and livestock in the affairs of nurseries to the marketing of agricultural products. Fisheries counseling covers all activities related to the processing and utilization of fish resources and their environment in sustainably from preproduction, production, processing to marketing. Forestry extension is a management system related to forests, forest areas and forest products that are carried out in an integrated and sustainable manner.

\section{Changes in Institutional Agricultural Extension in Central Java Province}

Since it was first formed until now, the institution of agricultural extension is always changing in each era. Institutional change is a process of permanent transformation which is part of the simultaneous development to create a new balance (Yustika, 2012). In Central Java Province the institutional change in agricultural extension is indeed aimed at improving the system and keeping abreast of the times.

The formation of agricultural extension institutions in Central Java Province was carried out by a team from the province namely the law firm and the regional autonomy bureau. Including drafting regional 
regulations, while in the service they only carry out their policies. The existence of agricultural extension activities in Central Java Province began in 1970 in the form of mass fostered programs (Bimas) when the Party of Work Group received the most votes during the presidential election. Then the agricultural service was made, the extension activities were structured from the center to the village in a command from the center. At that time also began the existence of farm business loans.

Government intervention in agriculture is very large. The institutional form of the farmers is formed starting from the farmer groups in the village, the agricultural extension center in the sub-district, the extension agent in the district, and the province deals with Bimas. Then the instructor is divided per discipline that consists of fisheries, animal husbandry, and plantations and agriculture into one. This form of institutionalization lasted until 1998 marked by a successful food self-sufficiency program. At that time, the instructor carried out polyvalent tasks incorporated in the Guidance.

After this reformation, the planned food policies are very diverse including rice selfsufficiency, food revitalization, food selfsufficiency, and food sovereignty. Recalling since it was first formed until now, the institution of agricultural extension is always changing. These changes include imposed institutional changes in which these changes are executed and initiated by governance. In the historical context, this institutional change in counseling is an evolution of common law. This is shown starting from the issuance of Law Number 22 Year 1999 concerning regional autonomy, then Law Number 16 of 2006 concerning the extension system for fisheries and forestry agriculture, then Law Number 14 of 2014 concerning regional government. So that the institutional history of agricultural extension is stopped by law.

The times and related to regional autonomy in 1999, extension workers began to be taken care of by the agricultural information center (BPIP). At that time the instructor was still carrying out tasks in a polyvalent manner. The division of tasks is based on the district area. Each sub-district has a coordinator in charge of 3 to 4 independent agricultural extension workers (PPS) with offices in the sub-district. Then in 2000 extension workers were delegated to their respective regions with the same official activities as they are now under the same department of agriculture. However, in 2002 each extensionist was assigned to their respective offices according to the agricultural background consisting of fisheries, agriculture, and forestry. After that the issuance of Law Number 16 of 2006 concerning Agricultural, Fisheries and Forestry Extension Systems contained the mandate to establish a Counseling Coordination Agency (Bakorluh). So that agricultural extension workers from various backgrounds become one department. This institutional form lasted until 2014 after the issuance of Law Number 14 of 2014 concerning the Regional Government.

Law Number 14 of 2014 began to be realized in 2016, even though Act Number 16 of 2006 has not been revoked. At that time Bakorluh was experiencing degradation. Institutional extension of fisheries into central government affairs (Ministry of Maritime Affairs and Fisheries) and then divided into 
several Basic Administrative Units (Satminkal) and then placed in each district, agricultural extension is still structured from the center to the district, and structured forestry extension from provinces to branches forestry areas where employment status is withdrawn to the provinces. From an institutional perspective like this, the National Coordination Agency (Bakornas) does not exist, Bakorluh does not exist, and the Agricultural and Fisheries Agricultural Counseling Center is again the Agricultural Counseling Center (BPP). The counselors are no longer institutionally united even though they still exist personally.

Extension as an integration service for the community. The task carried out by the instructor is a functional assignment regulated by the Ministry of Agriculture (Menpan). Extension agents are also officials who must synchronize their duties as officials and functional. Based on Law Number 16 of 2006 which is still valid, the task of extension is more concerned with human resources (HR) who divide the tasks according to capabilities consisting of agriculture, fisheries, and plantations. Even though Bakorluh's institution no longer exists, there are still agencies that can be considered institutional. It is not an extension institution, but only a government agency that conducts it in conducting extension activities. So that the nature of institutional counseling is not perfect. Based on the law, counseling activities continue to be carried out, counselors still exist even though the institution does not exist.

Every process of institutional extension changes based on laws and Regional Regulations (Perda). From 1998 until now the institution has changed. In the 1990s until
2000 the agency was called Mass Guidance (Bimas). After the regulation on regional autonomy policy, agricultural instructors are taken care of by the Agricultural Extension Information Center (BPIP) which is still one of the departments of agriculture.

In 2002, following with the regional autonomy policy, each instructor was delegated to their respective offices according to their expertise and background (fisheries, agriculture, and forestry). After the issuance of Law Number 16 Year 2016, related to the fisheries, agriculture and forestry extension systems in which regulating institutions in the central government there are the Ministry of Agriculture, the Ministry of Maritime Affairs and Fisheries, and the Ministry of Forestry where the Environment and Forestry currently has a field that handles extension workers . Structurally located in the Agricultural Human Resources and Development Agency (BPMPSDMP) and Fisheries BPPSDM. Where every cross-ministry there is a National Coordinating Board (Bakornas) chaired by the Minister of Economy. Underneath it, at the provincial level, a Counseling Coordination Agency (Bakorluh) was formed, in the district/city a Counseling Implementing Agency (Bapelluh) was formed, in the Districts a Counseling Center was formed, and in the village there was Posluhdes. So that each of these institutions handles all agricultural extension matters including fisheries and forestry.

After the issuance of Regional Regulation Number 23 of 2014 concerning the Government System, Bakorluh experienced degradation in 2016 after two years of promulgation. The existence of agricultural instructors is still structured from the center to 
the villages. Forestry extension officers are recruited to the province, not only extension agents but also their services, while fisheries extension agents are drawn to the center, then placed in various cities based on Satminkal. At present Bakornas and Bakorluh no longer exist, the Extension Centers in the sub-districts have changed to become Agricultural Extension Centers (BPP). Extension agents are no longer institutionally integrated.

Institutional changes are followed by changes in program nomenclature, even though the actual realization is the same. Extension officers placed in service are functional officials who should carry out their functions accordingly. But in reality, agricultural extension workers are still doing additional work in the form of administrative work. The minimal number of extension workers is still a classic problem that causes counseling to be prioritized. So that the role of self-help counselors is needed to support the implementation of agricultural extension activities.

Based on the results of the triangulation it can be concluded that the institutional change in extension is very dynamic from the start of the formation of the institution. If identified based on the cause of the cessation of institutional history, these institutional changes include imposed institutional changes in which these changes are executed and initiated by government orders or law (Lin 1989: 13 in Zhang, 2012: 991). If identified based on a model of institutional change occurring in the historical context of Scoot in Challen (2007: 47), then this institutional change includes the evolution of the common law (evolution of common aw). The situation that occurred in Central Java Province, changes in the agricultural extension institutions have made the policy process, roles and responsibilities, incentives, and legal frameworks change.

\section{Impact of Changes in Institutional Education for Peasant Communities in Central Java Province}

Agricultural extension is an informal education that seeks to bring change, knowledge, attitudes, and activities of clients following the elements of education through a participatory approach (Rahim M Sail in Prajanti, 2011). Extension activities in Central Java Province are carried out by extension agents supported by self-help extension agents.

The involvement of extension agents in agricultural activities in Central Java Province can be seen from the existence of farmer groups where each group leader is educated to be a self-help extension agent. The role of extension agents and self-help in forestry activities is needed. Especially for agricultural citizens who are not members of farmer groups. The importance of the role of extension workers so that all communities understand the steps in innovation about forestry agriculture, care, eradicate pests, and proper cultivation. The involvement of extension workers in agricultural forestry activities has been felt by farm families. This is felt from changes in fruit growth that was previously less than the maximum due to the influence of the drug. After the counselor gives guidance and invites fruit experts, the yield is better.

Counseling conducted by extension services had an impact on the community. 
These impacts are in the form of positive and negative impacts. The positive side for farmers after counseling is that extension agents can change the mindset of farmers who still think in the past when conducting agricultural activities to be more modern by innovations. The people do what is called upon by the experiments of the farmers. This has become an advantage for farmers to take part in counseling. But there are still people who have not implemented it because it still follows the traditional way. Assuming that the more plants will produce more results. Though it is not certain.

Before counseling, farmers planted in the forest carelessly and irregularly. All commodities are planted without regard to proper planting procedures. After the guidance from the instructor, the way to grow farmers is better because there are groupings when planting. Starting from the classification of types of plants, the use of fertilizers and fertilizers, and plant management techniques.

The change has been felt by farmers, from what was previously "opo-opo" (Javanese language it's mean everything), requiring to be blocked (anything planted as long as it is dropped) becomes more organized because it is grouped. The grouping consists of fruit plants, protective perennials, the use of fertilizers, and planting methods. The program that is being intensified at this time is planting rice with relief ranks but it is still a little difficult to change the mindset where the more plants will get more results. After this counseling, agriculture, and forestry became more organized and more advanced.

Evaluation of improvements to the implementation of counseling that so far has been felt by farmers and independent extension workers has not been intensive. This is because every change in paramedics (extension agents) will be different programs. There are still many forestry matters that have not yet been achieved. Especially vulnerable when counseling is only 3 or 6 months if from the department. So it is more effective if the counselor is a self-help counselor who can be asked at any time.

So far, the independent forestry extension service and official service have coordinated with each other so that the community will continue to receive counseling from independent extension agents. This does not mean that extension agents are not capable in terms of knowledge, but rather a very limited number and still get other work in the office. After that, the instructor will evaluate to find out the shortcomings of the implementation of agriculture, so they can know what needs to be fixed and what to do in the future.

The perceived shortage is agricultural capital. But that is very much ruled out, because the farmer groups, as possible, are looking for funds to fulfill it. The spirit of farming is also a barrier. This is because interest in becoming a farmer is especially diminishing for young people, so self-help extension agents are intensifying how to make agriculture not just for food. But it can be an advanced and dependable industry.

Farmers and independent extension agents also feel the shortage of extension agents. This is because many things are by the main tasks and functions of extension services that have not yet reached the farmers directly. So it is necessary to increase the number of official extension agents. Beside, coordination between agencies should be improved so that 
the green belt lands do not become buildings. So that land use change can be reduced.

The implementation of counseling should increase the intensity of time. Self-help educators and farmers want an evaluation at least every 3 months. However, in reality on the ground, more than three months have been evaluated. This is also due to the limited number of extension workers so that the implementation of extension workers has not been evenly distributed. Another expectation from farmers is to want the government to embrace farmers more and coordinate especially in terms of investment from the private sector which sometimes harms surrounding farmers. Even though the land has been leased to the private sector, farmers hope that they still have the opportunity to participate in managing their land. So that the desire of farmers who are still eager to farm so that agriculture does not only meet their daily needs but can be an advanced industry and economic development priorities can be achieved.

Based on the results of the study it can be seen that the involvement of the government has been felt by the community to increase the productivity of farmers through extension activities. This is felt by farmers because extension agents have provided innovations in agriculture, especially in the field of forestry, extension agents participate in planting trees. The advantage gained by farmers by changing institutional counseling is that the knowledge obtained by farmers is more specific to the agriculture, fisheries and forestry sectors. But the loss is also felt by the community because the number of instructors is very minimal so that the extension agent is required, while the loss felt by the instructor is to make the target priority so that the extension activities can run well.

\section{The existence of Institutional Agricultural Extension in Central Java Province}

The changing institution of agricultural extension in Central Java Province is a form of revitalization of the agricultural system. Institutional change causes institutional existence to change. Existence is not rigid and stagnant but is flexible and develops or vice versa depends on being able to actualize its potential (Zainal 2007: 16).

Basically, the community does not pay much attention to changing institutions. It's just that in the case of submission of assistance, each farmer group must submit to the service by the commodity planted by farmers. It is different as it used to be that it can go to one agency, immediately get forest, agriculture, and fisheries commodities. Considering that most farmer groups in Central Java Province work side by side in utilizing land. In terms of imports, the institution is less effective due to a lack of cooperation. A common occurrence where the Ministry of Trade wants imports, even though it will be harvesting soon. This is due to information from the public regarding the exact planting calendar not being conveyed to the center. Considering that many extension institutions have been lost, their existence has diminished. However, so far the institutional changes still have a good effect because it is more organized and more focused.

Agricultural instructors who often intersect with the community consist of civil servants (extension agents), self-help Each instructor is obliged to foster and provide 
examples. Although sometimes private extension workers who are from companies whose interests offer products, the knowledge shared with the community is also useful. Among the instructors are often collaborating like coordination in carrying out counseling in the community. Collaboration between sectors in the technical field and cooperation in terms of increasing the competency of agricultural human resource (HR). Even though self-help counselors are still being targeted by extension agents. This is in the form of knowledge transfer so that knowledge from the department can be conveyed to the public. Given the limited number of extension agents, so extension agents need self-help extension agents who are the main actors of agriculture to share their knowledge with the farming community.

Assessment to evaluate and spur the implementation of extension workers through assessing the target group has reached what level. So if the group is still at the beginner level, then the intensity becomes the target torches more often. Not that the intermediate will leave, but will continue to be counseled, although not often. Even though they are already in the middle of it, if they are not informed,the group will likely disband. So that the evaluation will be carried out continuously so that the instructor knows what the shortcomings are when guiding. In this case, the instructor strives for all groups to receive counseling fairly. However, due to limited numbers, there are priorities.

How to evaluate forestry and agriculture instructors is almost the same as fisheries extension workers. It's just that it can be done at the provincial level. Evaluation of the performance of counseling is done individually to raise credit scores. This assessment is compiled in the form of an activity report as a reference for preparing the Annual Work Plan and raising it to the next level. Evaluation is done based on the plan arranged by the instructor. So that the lack of planning will be used for improvement in the following year.

Fisheries instructors responding to the absence of Bakorluh institutions is not a problem. When it comes to position, it should be functioned according to its function. Actually, the fisheries instructor is not a structural official, but a functional official, so whatever the institutional form the extension task must be carried out. The instructor expects the institutional extension of fisheries to reach regency, so that it can accommodate the interests of the instructors and fisheries business actors. This is considering that the institution is far away and requires a long time. Even though technology already exists, the range of long distance constraints still exists. Especially $\mathrm{BP}_{3}$ Tegal which is the center of Central Java, DIY, West Kalimantan, and East Kalimantan.

Whatever is still an obstacle does not reduce the enthusiasm of the instructors and does not reduce the quality of extension workers to work with the existing institutional overshadow. The visits, reports, and reports are still ongoing. Other hopes that the institution will be better, especially in paying attention to the fate of the counselors. So that extension agents can carry out functional task, because so far the instructors and even civil servants are sometimes uncertain. This is because it is the job of the instructor to foster human resources, the results of which do not immediately seem to have increased 
production but change behavior, attitudes, and science.

Forestry extension agents respond based on the facts on the ground that agriculture, forestry, and fisheries cannot be separated. The community recognizes Field Agricultural Extension (PPL) as extension agents who understand the three agricultural commodities. Actually, it is more effective to be merged according to the $\mathrm{SP}_{3} \mathrm{~K}$ Law so that counselors can go to the field together if it is to the community, especially those who use land in an intercropping manner. So that extension workers are separated by technical services. So that farmers can look for extension agents to one place. But given the current situation, the form of service is not an implementation point. It's just that wherever the instructor is located, assigned according to their functions and assigned according to their functions, is not equated with implementing staff with different levels of office.

Agricultural extensionists hope for the return of instructor functions according to their functional functions that are technically functional. The instructor must know how the problem is in the field, how to do it in the field, so the instructor knows how to deal with and synchronize counseling material. For example, before the extension agent must know how endemic the torch target area is, then to complete it by making a joint study and evaluation. The point is that the extension agency will be more ideal if it stands alone following the $\mathrm{SP}_{3} \mathrm{~K}$ Law. However, when considering the current situation, at least the instructor is functional and does not concurrently perform other administrative tasks.

To improve the performance of extension agents, forestry extension agents, agricultural extension agents, and fisheries extension workers have their respective efforts. Fisheries instructors who are related to improving performance are often included in training activities, even if there is an apprenticeship of business actors, the instructor is included as a companion as well as a participant. The training is more often done at $\mathrm{BP}_{3}$ Tegal.

DLHK's plan to improve performance has recently been increased in benefits and infrastructure in the form of motorbikes. Although those who already have a motorcycle prefer to use a private motorcycle. In addition to motorbikes, other supporting tools such as the Global Positioning System (GPS). Meanwhile, to improve the quality of human resources, training and facilitation will be carried out for competency tests, gatherings, technical guidance, special material, and motivation to improve performance by the Governor of Central Java Province as the supervisor.

Efforts to improve the performance of instructors by Distanbun through increased competence as measured through competency tests. But unfortunately, this competency test has not been used for certification such as teachers with good relations. So far it is useful for promotion in the form of beginner and intermediate levels. This promotion is determined by the performance improvement in preparing credit figures. If the instructor's performance decreases, the instructor maybe terminated. 
Based on the results of the triangulation above, it can be concluded that currently, the agricultural extension institutions do not exist, because the institutions are no longer available. Institutional is only part of the department for agriculture and forestry, while fisheries extension is part of the Tegal Fisheries Counseling and Training Center. Even though agricultural institutions are no longer available, the functional position of extension workers must continue to provide information to the community. So that until now the instructor is still and must exist even though the institution is gone.

\section{CONCLUSION}

Institutional changes in post-reform agricultural extension in the Province of Central Java include institutional changes imposed (institutional change) in which these changes are executed and initiated by governance. In the historical context, this institutional change in counseling is an evolution of the common law.

Institution of agricultural extension is very existent after the issuance of Law Number 16 of 2006 concerning agricultural extension services for fisheries and forestry because after this there was a Bakorluh that brought together all agricultural extension agents into one service. At present, the agricultural extension institution has not existed since 2016 exactly two years after Law Number 14 of 2014 was issued.

The impact of institutional changes in agricultural extension for the community is known from government involvement, weaknesses, and strengths after the change. The involvement of extension agents in the farming community is good. This is marked by a change in the mindset of farmers who are increasingly advanced marked by accepting new innovations in agriculture. It is recommended that extension agents carry out online monitoring to self-help extension workers and farmer group leaders as farmers' representatives. Given the number of extension workers who are still minimal, so in the implementation there are priorities. So that self-help counselors will still get knowledge theoretically to match the knowledge implemented by self-help extension agents as the main actors. In addition, the need for self-help counselors is given more attention, especially in terms of training and organizing counseling.

Institutional changes in post-reform agricultural extension in the Province of Central Java include institutional changes imposed (institutional change) in which these changes are executed and initiated by governance. In the historical context, this institutional change in counseling is an evolution of the common law. In the near term, the improvement of agricultural extension institutions should make adjustments to the main tasks and functions of extension workers by functional positions.

In the long term, agricultural extension institutions should be re-created services such as Bakorluh so that extension agents when carrying out tasks in the field can be shared between agriculture, fisheries and forestry, especially when to areas that use land in overlapping.

Efforts can be made to maintain the institutional function of agricultural extension for farmers by increasing the means of supporting activities and increasing the number of agricultural extension workers. In 
the field, instructor constraints often occur when going to hold agricultural pilot activities. However, facilities are often constrained so that farmers do not want to follow the advice of farmers.

\section{REFERENCES}

Abidin, Zainal. (2007). Existence Analysis An Alternative Approach to Psychology and Psychiatry. Jakarta: Raja Grafindo Persada.

Afrizal. (2017). Qualitative Research Methods An Effort to Support the Use of Qualitative Research in Various Disciplines. Depok: PT Rajafindo Persada.

Agustono (2013). Analysis of the Agriculture Sector in Terms of Role in Growth and Stability of Gross Regional Domestic Product in Central Java Province. SEPA: Vol. 9 Number 2. Hal: 283-296. Surakata: Eleven March University.P

Maritime and Fisheries Human Resources and Research Agency. (2017). 2017 BRSDM Performance Report Jakarta: Maritime and Fisheries Research and Human Resources Agency.

Central Bureau of Statistics. (2018). Central Java Province in Figures. Semarang: Central Statistics Agency.

Afrizal. (2017). Qualitative Research Methods An Effort to Support the Use of Qualitative Research in Various Disciplines. Depok: PT Rajafindo Persada.

Bungin, H. (2017). Qualitative Research in Communication, Economics, Public Policy, and Other Social Sciences. Jakarta: Kencana.

Cooper, D., \& Schindler, P. (2017). Business Research Methods 12th Edition Book 1. Jakarta: Salemba Empat.
Haris, S. (2014). Problems of Democracy \& Nationality in the Reformation Era. Jakarta: Indonesian Torch Library Foundation.

Haryono, D. (2014). Policy Reform Towards Transformation of Agricultural Development. Jakarta: IAARD PRESS.

Nuhung, I. A. (2016). Agricultural Strategies \& Policies in Competitiveness Perspectives. Jakarta: PT RINEKA CIPTA.

Prajanti, S. D. (2011). Strategy for Strengthening Agricultural Extension Worker Performance. Semarang: UNNES PRESS.

Saputri, Rusita Dewi. (2016). The Role of Field Agricultural Extension Workers with Development Level of Farmer Groups in Sukoharjo Regency. Agrista: Vol. 4 Bo. September 3, 2016: P.341-352, 341-352.

Sugiyono (2012). Educational Research Methods: Qualitative, Quantitative, and R\&D Approaches. Bandung: Alfabeta.

Sunarto, \& et al. (2015). Citizenship Education in Higher Education. Semarang: UNNES MKU-MKDK Center.

Waluyo, E. A., Ulya, N. A., Kunarso, A., \& Syahbana, T. A. (2016). The existence of Institutional Water Management in Perapau Sub-watershed. Proceedings of the Exposure of Research Results (pp. 241-312). Palembang: Palembang Research and Development Center for Environment and Forestry.

Yustika, A. E. (2012). Institutional Economics Paradigms, Theories, and Policies. Jakarta: Erlangga Publisher. 